\title{
RELIGIOUS IDENTIFICATION AND ATTITUDE TOWARD ECONOMIC INVOLVEMENT AMONG CHRISTIANS AND MUSLIMS IN RUSSIA
}

\begin{abstract}
M.V. EFREMOVA ${ }^{a}$, Z.KH. LEPSHOKOVA ${ }^{a}$
${ }^{a}$ National Research University Higher School of Economics, 20 Myasnitskaya Str., Moscow, 101000, Russian Federation

Abstract

This study presents the results of empirical research into the relationship between strength and positivity of religious identification and attitudes towards economic behavior in a group of Orthodox Christians and Sunni Muslims in Russia $(\mathrm{N}=820)$. In order to measure strength and positivity of religious identification, we used two components based on the Social Identity Theory. Attitudes toward models of economic behavior were measured through economic attitudes based on a scenario approach. The results revealed that attitudes towards three models of economic behavior can be clustered into a single economic involvement factor. In addition, generalized economic involvement was confirmed by CFA in both religious groups. In our study we found that strength and positivity of religious identification are differently associated with attitudes toward economic involvement in the two groups. Thus, it was concluded that the strength of religious identification negatively related to attitudes reflecting economic involvement. Positivity of religious identification was found to have a positive association with economic involvement. However, the further MGSEM demonstrated that the relationship between positivity of religious identification and economic involvement had interfaith specifics: positivity of religious identification was positively related to the models of economic involvement only in the group of Christians, while in the group of Muslims this relationship was insignificant. The results are discussed in terms of features of religious identification in these two groups.
\end{abstract}

Keywords: religious identification, economic attitudes, models of economic behavior, economic involvement, Christians, Muslims, Russia.

\section{Introduction}

Although research on the role of religion in human behavior originated more than a century ago (Weber, 1978), the defining nature of religion in our lives still remains a controversial issue (Iannaccone, 1998).

The article was prepared within the framework of the Basic Research Program at the National Research University Higher School of Economics (HSE) and supported within the framework of a subsidy by the Russian Academic Excellence Project "5-100". 
However, religion as a socially sustained system of beliefs, values, norms, symbols, and practices (Cohen, 2009) continues to play an important role in the lives of people in most societies (Iannaccone, 1998; Parboteeah, Paik \& Cullen, 2009). The present study examines differences in the relationship between strength and positivity of religious identification, and models of economic behavior. The relevance of the study is determined by several factors. First, the role of religious identification, which also functions as a factor of ethnic differentiation and integration, has increased in recent years (WIN - Gallup International Association, 2012). Second, the present study does not focus on macroeconomic and social problems, but rather on social and economic attitudes and models of peoples' behavior that are often imbued within a culture and eventually determine the socioeconomic development of a country (Basedau, Gobien, \& Prediger, 2018; Guiso, Sapienza, \& Zingales, 2006).

The novelty of the study is the focus on the role of strength and positivity of religious identification at increasing attitudes toward economic involvement.

Previous empirical research indicated that there is a stable relationship between religious affiliation and economic attitudes (Dana, 2009; Parboteeah et al., 2009; Hayward \& Kemmelmeier, 2011). Several studies suggest that religion has a regulatory effect on individual economic behavior (Barro \& McCleary, 2003; Benjamin, Choi, \& Fisher, 2010; Putnam, 1993; Dana, 2009). What is the nature of that effect? To answer this question, some studies indicate that religion is positively correlated with attitudes that favor the free market and its institutions. The results of a study conducted on a sample of representatives from six religious groups (Catholics, Protestants, Jews, Muslims, Hindus, and Buddhists) reveal that religious people tend to be more trustful towards others and the state, and are more likely to believe that market outcomes are fair. On the other hand, they investigated the effect of religiosity in relation to women's rights but results showed a less tolerant and less sympathetic correlation. Religiosity correlates with a higher emphasis on thrift, strong feelings of individual responsibility (Guiso, Sapienza, \& Zingales, 2003). At the same time, other studies demonstrate that religion can be seen as a source of conflicts that hinder effective management in different cultures (Parboteeah et al., 2009).

The question of exactly which psychological characteristics form the basis for the differences between religious and non-religious people and to what extent they may be manifested in the socioeconomic sphere were partly clarified in a study by Schwartz and Huismans (1995) where it was established that religiosity is negatively associated with the values of Achievement, Stimulation, and Self-Direction. This finding suggests that the opposition of self-enhancing, materialistic aspects of Achievement values and the Self-transcending anti-materialism of religious teachings may constitute a rather important link between these values and religiosity.

A number of studies explain the positive relationship between religiosity and individual achievements by referring to the influence of religious norms (Ellison, 1991; Freeman, 1986). In this context it should be emphasized that the majority of studies examining the role of religious identification focus on major religions (such as Christianity, Islam, Judaism, and Buddhism) without taking into account the internal divisions, each bearing different religious norms. Based on the results of a 
series of cross-denominational studies, Parboteeah, Paik and Cullen (2009) suggest that people belonging to all forms of Christianity share the same attitude to work. However, it was found that there are differences in values in relation to work among representatives of Protestantism, Catholicism, and Orthodoxy.

These empirical results indicate that the analysis of the relationship between religious identification and economic attitudes and perceptions requires a consideration of the features of a particular religion's beliefs. More specifically, in Orthodoxy this relationship has an antinomic character: from an Orthodox perspective, any economic activity may be both good and bad depending on "the motivation behind it, the purpose of the activity" (Koval', 1994, p. 66). Orthodoxy does not have a specifically developed and theologically sound economic ethics. Conversely, Protestantism provides greater freedom and mobility, thus the Christian doctrine of morality requires a greater responsibility and places a greater emphasis on personal faith than on universal obedience. On the contrary, all aspects of a Muslim's life are governed by Islamic law (Sharia). This results in a specific status of Islamic identification in the sense that Islam is "not only a religion but a secular social system” (Kudryashova, 2012, p. 158). By institutionalizing virtually all spheres of human life and society, "Islam becomes a way of life" (Albakova, 2009, p. 37). As social identification is defined as an awareness of belonging to a group, the adoption of values, attitudes, and norms important for members of this group (in this case, religious ones) is the outcome of identification.

Components of religious identification. Our study views religious identification as a multidimensional construct (Allport, 1950; Glock, 1962) and, as a part of social identification, it includes cognitive, emotional, and behavioral components (Glock, 1962; Elçi, Şener, \& Alpkan, 2011). These components are relatively independent (Ashmore, Deaux, \& McLaughlin-Volpe, 2009) and each of them has a corresponding impact on the formation of attitudes and patterns of individual behavior inasmuch as religious identification does not form by itself but in conjunction with other components of social identification (Ammerman, 2003). The behavioral component is less universal for representatives of the two religions being investigated, therefore it was excluded from our analysis. In the present study, we focus on two elements: strength and positivity of religious identification. Subjective religiosity is a universal construct for both Christianity and Islam, which adequately reflects affiliation to a religious group. It seems plausible to study the affective component of religiosity in terms of positivity of religious identification since previous research demonstrated that it leads to positive outcomes of identification (Amiot \& Sansfaçon, 2011; Tajfel, 1978).

This study analyses the relationship between the strength and positivity of religious identification and models of economic behavior in a group of Orthodox Christians and Sunni Muslims.

\section{The model of economic behavior and economic involvement}

Researchers emphasized different aspects of economic behavior, and thus it is conceptualized in many different ways. Some defined economic behavior as a specific 
behavior in the economic sphere of one's life (Lea, Webley, \& Levine, 1993; Lea, 1999). Others viewed it as any behavior that relates to money, time or effort (Webley, Burgoyne, Leo, \& Young, 2001). However, neither definition includes all possible types of economic behavior. Nowadays, there are several specific directions in economic behavior research (Kirchler \& Holzl, 2006). Researchers are focusing on aspects of economic behavior, such as consumer behavior, financial behavior (including investments), entrepreneurship, and job market behavior. The variety of theoretical approaches to personality in psychology results in a variety of models of economic behavior. In the present study, we define attitudes towards economic behavior as economic involvement. Although economic involvement does not relate to specific types of economic behavior, it reflects the level of economic activity. We study attitudes towards economic behavior using a scenario approach (Smith et al., 2002) that helped develop models of economic behavior (scenarios for economic involvement were designed by members of the ScientificEducational Laboratory of Socio-Psychological Research at HSE in 2010). Individuals with high economic involvement will score highly for economic independence in decision making, economic activity, and orientation toward long-term planning in economic behavior. We tested this theoretical assumption using CFA. It is important to note that models of economic behavior reflect attitudes towards behavior and not behavior itself. We use the term "models of economic behavior" further in the text.

\section{Strength of religious identification and models of economic involvement}

Based on the results of past studies, we formulate the following hypothesis. Despite significant differences in the postulates of faith, representatives of different religions share the same basic moral principles of social and economic ethics and prioritize spiritual values over material ones. Therefore, we hypothesize that (H1) the strength of religious identification is negatively related to attitudes of economic involvement defined as economic activity, independence, and long-term perspectives in economic behavior (Figure 1).

Figure 1

The Model of the Relationship between Strength and Positivity of Religious Identification and Economic Involvement

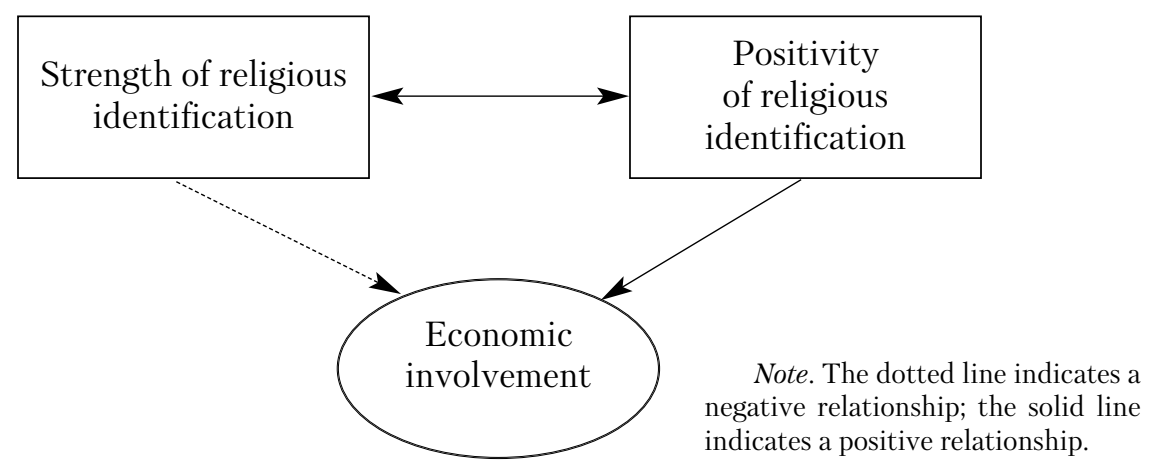




\section{Positivity of religious identification and models of economic involvement}

Past research has suggested that three components of social identification (cognitive, evaluative, and emotional) are empirically distinct and relate differently to key outcome variables (Bergami \& Bagozzi, 2000). The emotional component has been shown to most clearly "supply the motivational force" leading to action or the "readiness to engage in or disengage from interaction" (Ibid., p. 563).

Psychological well-being is one of the outcomes of positive religious identification, and also an affective component of social identity (Ashmore et al., 2009; Greenfield \& Marks, 2007). Psychological well-being is positively related to phenomena that reflect the active orientation of an individual, allowing them to restructure individual life goals and improve their quality of life, e.g. autonomy, self-actualization, dispositional and learned optimism (Csikszentmihalyi, 1999). Each of these phenomena reflects an individual's active orientation. Therefore, we hypothesize that $(\mathrm{H} 2)$ positivity of religious identification is positively related to attitudes of economic involvement defined as economic activity, independence, and long-term perspectives in economic behavior (Fig. 1).

\section{Method}

Participants. The study presents the results of a survey conducted in Russia (Moscow, Kazan', Penza, Vladikavkaz, Nazran', Grozny, Stavropol'). The sample included 820 people: 392 men and 428 women aged 15-70 $(\mathrm{M}=34)$. The sample consisted of representatives of two denominations: Orthodox Christians $(\mathrm{N}=559)$ and Sunni Muslims $(\mathrm{N}=261)$. Social demographic characteristics are presented in Table 1.

Regarding education, $1.7 \%$ respondents had incomplete secondary education (4.8\% of Christians, $1.1 \%$ of Muslims); $29.5 \%$ of respondents had complete secondary

Table 1

Socio-Demographic Characteristics of the Sample

\begin{tabular}{|c|c|c|c|c|c|c|}
\hline \multirow{2}{*}{$\begin{array}{c}\text { Religious } \\
\text { groups }\end{array}$} & \multirow{2}{*}{ Ethnic groups } & \multirow{2}{*}{$\mathbf{N}$} & \multicolumn{2}{|c|}{ Gender } & \multicolumn{2}{|c|}{ Age } \\
\hline & & & Male & Female & Mean (SD) & Range \\
\hline $\begin{array}{l}\text { Orthodox } \\
\text { Christians }\end{array}$ & $\begin{array}{l}\text { Russians } \mathrm{N}=486 \\
\text { Ossetians } \mathrm{N}=53 \\
\text { Ukrainians } \mathrm{N}=6 \\
\text { Armenians } \mathrm{N}=6 \\
\text { Chuvashs } \mathrm{N}=3 \\
\text { Evens } \mathrm{N}=5\end{array}$ & 559 & 269 & 290 & $36.3(13.8)$ & $15-70$ \\
\hline $\begin{array}{l}\text { Sunni } \\
\text { Muslims }\end{array}$ & $\begin{array}{l}\text { Russians } \mathrm{N}=34 \\
\text { Ingushs } \mathrm{N}=107 \\
\text { Chechens } \mathrm{N}=77 \\
\text { Ossetians } \mathrm{N}=3 \\
\text { Tatars } \mathrm{N}=40\end{array}$ & 261 & 123 & 138 & $31.5(12.8)$ & $17-60$ \\
\hline
\end{tabular}


or specialized secondary education (51.3\% of Christians, $29.9 \%$ of Muslims); 48.4\% of respondents had higher education, i.e. bachelor's, or master's degree (38\% of Christians, $43.3 \%$ of Muslims). 76.5\% respondents had a job (77.1\% of Christians, $75.1 \%$ of Muslims).

\section{Measures}

\section{Independent variables: Religious identification}

Respondents were asked to rate the strength of their religious identification by answering the question "How would you rate your level of religiosity?" on a 7point scale: this item was retrieved from the European Social Survey (ESS, 2010). We constructed a question to measure the degree of positivity of religious identification. Respondents were asked to assess the type of feelings they associated their religion with on a 7 -point scale, with 1 as "very negative" and 7 as "very positive".

\section{Dependent variables: Models of economic behavior}

To identify the models of economic behavior, specifically "economic involvement", we used a methodology of economic behavior scenarios which allows the identification of economic attitudes. This methodology is based on the scenario approach that was developed in the Scientific-Educational Laboratory of SocioPsychological Research at HSE in 2010. It was validated on a sample of 424 respondents in two cities in Russia (Tatarko et al., 2011). The respondents were given a description of a scenario and were then asked to evaluate the situation using two scales: one assesses their willingness to act in the same way as in the vignette (the behavioral component of the attitude) and the other measures the emotional preference for this behavior (the affective component of the attitude). Each indicator of economic behavior has a bipolar dimension.

We included several scenarios of economic behavior in order to measure the level of economic involvement. These scenarios are economic paternalism vs. independence; focus on long-term vs. short-term perspective in economic behavior; economic activity vs. passivity.

For each situation, respondents were asked to evaluate the behavior of two people on a 7 -point scale indicating:

(a) the behavior of the person who they liked the most and to what extent (the “Emotional preference" scale) (-3 - I like Alexander's behavior more; 0 - I don't know; 3 - I like Vasily's behavior more);

(b) how likely the respondent was willing to act similarly to one of the characters (the "Willingness" scale) (-3 - I would do as Alexander did; 0 - I don't know; 3 - I would do as Vasily did).

The situations were designed so that the behavior of one character reflects one pole of the dimension of economic behavior, and the behavior of the second reflects the opposite pole of this dimension, i.e. Alexander and Vasily's behaviors are opposite. 
The personal data set included questions on the respondent's age, sex, education, place of study/work, employment status and nationality. We used education and employment status as control variables.

Procedure. A questionnaire in Russian was individually completed by respondents in the interviewer's presence. The average time for filling in the questionnaire was approximately 25 minutes.

Data analysis. We compared means using Student's $t$-test. We also performed CFA in order to test the factorial structure of the model. To identify relationships between the variables, we used multi-group structural equation modelling (MGSEM) using the maximum likelihood estimation method. The data was analysed using SPSS 22 and AMOS (Version 22).

\section{Results}

Table 2 presents the means and standard deviations. The mean score for the Sunni Muslims on the positivity of religious identification measure is close to the scale's upper limit and the standard deviation is relatively low, suggesting a ceiling effect. In total, $53.6 \%$ of the participants had the maximum score of 7 on this measure and $93.8 \%$ had scores of 5 or above. On all other measures, the mean score is around the scale midpoint and the range is wider. Not surprisingly, due to the lack of variability in the range of responses for this measure, positivity of religious identification was not associated with economic involvement.

We found significant differences between the two religious groups in attitudes toward economic independence. Economic independence is significantly higher in the group of Muslims than in the group of Christians. Cohen's d coefficients are relatively low. This means that the differences might depend on the sample sizes.

Table 2

Means and Standard Deviation

\begin{tabular}{|c|c|c|c|c|c|c|}
\hline \multirow{2}{*}{ Variables } & \multicolumn{2}{|c|}{ Orthodox Christians } & \multicolumn{2}{|c|}{ Sunni Muslims } & \multirow{2}{*}{ t-test } & \multirow{2}{*}{ Cohen's d } \\
\hline & $\mathrm{M}$ & $\mathrm{SD}$ & M & $\mathrm{SD}$ & & \\
\hline \multicolumn{7}{|l|}{ Independent variables } \\
\hline $\begin{array}{l}\text { Strength of religious } \\
\text { identification }\end{array}$ & 3.79 & 1.22 & 5.05 & 1.37 & $-13.15^{* * *}$ & .97 \\
\hline $\begin{array}{l}\text { Positivity of religious } \\
\text { identification }\end{array}$ & 5.11 & 1.24 & 6.19 & 0.91 & $-12.17^{* * *}$ & .99 \\
\hline \multicolumn{7}{|l|}{ Dependent variables } \\
\hline Economic independence & 3.56 & 1.41 & 3.95 & 1.30 & $-3.77^{* * *}$ & .28 \\
\hline $\begin{array}{l}\text { Long-term perspectives } \\
\text { in economic behavior }\end{array}$ & 3.53 & 1.42 & 3.58 & 1.29 & -0.41 & .03 \\
\hline Economic activity & 3.63 & 1.40 & 3.69 & 1.34 & -0.65 & .04 \\
\hline
\end{tabular}

$* * * p<0.001$. 
The next section consists of two parts: in the first part the results of CFA run with variables measuring models of economic behavior are presented; in the second section we focus on the results of SEM.

We assumed that economic involvement forms a single factor derived from the three scenarios of economic independence, long-term perspectives in economic behavior, and economic activity. Each of them is the result of a combination of emotional preference and willingness scales. Therefore we tested the model using CFA on the combined sample $(\mathrm{N}=820)$. The model is presented in Figure 2.

Characteristics of the model are the following: $\mathrm{CMIN} / \mathrm{DF}=3.22$; CFI $=.99$, RMSEA $=.05$, PCLOSE $=.40$. The model characteristics fit our data well enough to confirm the existence of one factor of economic involvement. Then we tested the resulting scales for scalar invariance in a multi-group simultaneous CFA with two religious samples. The characteristics of the model are: $\mathrm{CMIN} / \mathrm{DF}=1.65 ; \mathrm{CFI}=.99$, RMSEA $=.03$, PCLOSE $=.91$. Full scalar invariance was CFI $=.001$. Table 3 shows the standardized regression weights of the variables included in the economic involvement factor for the combined sample and both religious samples.

The models of economic behavior that form the factor of economic involvement have significant regression coefficients that confirm the overall and interfaith validity of the creation of the unified economic involvement factor.

The results of CFA demonstrated that the concept of economic involvement reflects the willingness to be economically independent, active, with the desire and willingness to build long-term prospects for economic behavior.

Prior to conducting the MGSEM on the groups of Orthodox Christians and Sunni Muslims, we compared means of religious identification in these two groups. $t$-test showed that strength and positivity of religious identification were significantly higher $(p<0.001)$ among the Muslims (5.11 and 6.19, respectively) than among the Christians (3.79 and 5.05).

Figure 2

The Model of Economic Behavior with the General Economic Involvement Factor

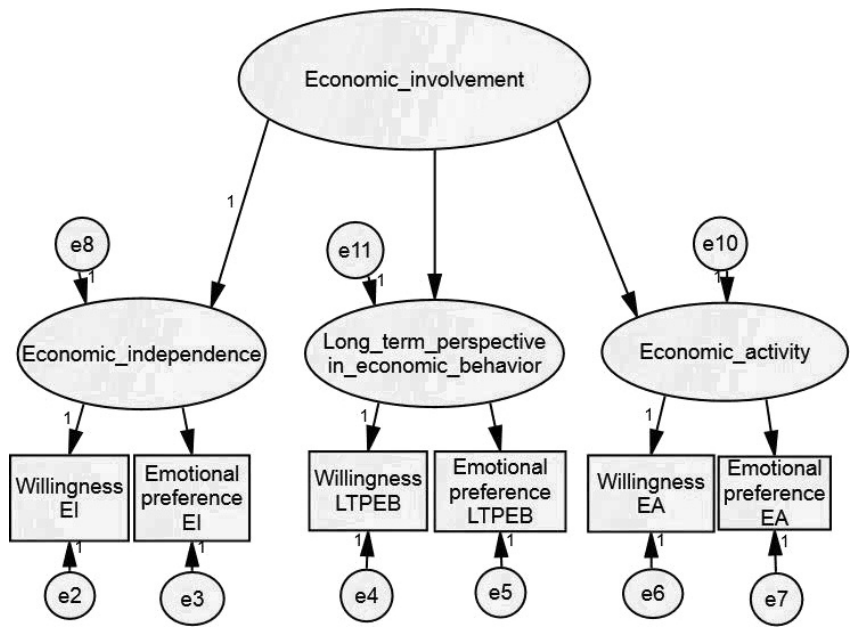


Standardized Factor Loadings for the Models of Economic Behavior (Economic Involvement Factor)

\begin{tabular}{|c|l|c|c|c|}
\hline \multirow{2}{*}{ Factor } & \multicolumn{1}{|c|}{ Models of economic behavior } & $\begin{array}{c}\text { Combined } \\
\text { sample }\end{array}$ & $\begin{array}{c}\text { Christian } \\
\text { Orthodox }\end{array}$ & $\begin{array}{c}\text { Sunni } \\
\text { Muslims }\end{array}$ \\
\hline \multirow{2}{*}{$\begin{array}{l}\text { Economic } \\
\text { involvement }\end{array}$} & Economic independence & $.74^{* * *}$ & $.78^{* * *}$ & $.60^{* * *}$ \\
\cline { 2 - 5 } & $\begin{array}{l}\text { Long-term perspective in economic } \\
\text { behavior }\end{array}$ & $.62^{* * *}$ & $.72^{* * *}$ & $.39^{* * *}$ \\
\cline { 2 - 5 } & Economic activity & $.73^{* * *}$ & $.71^{* * *}$ & $.83^{* * *}$ \\
\hline
\end{tabular}

$* * * p<0.001$.

Figure 3

The Model of the Relationship between Strength and Positivity of Religious Identification and Economic Involvement

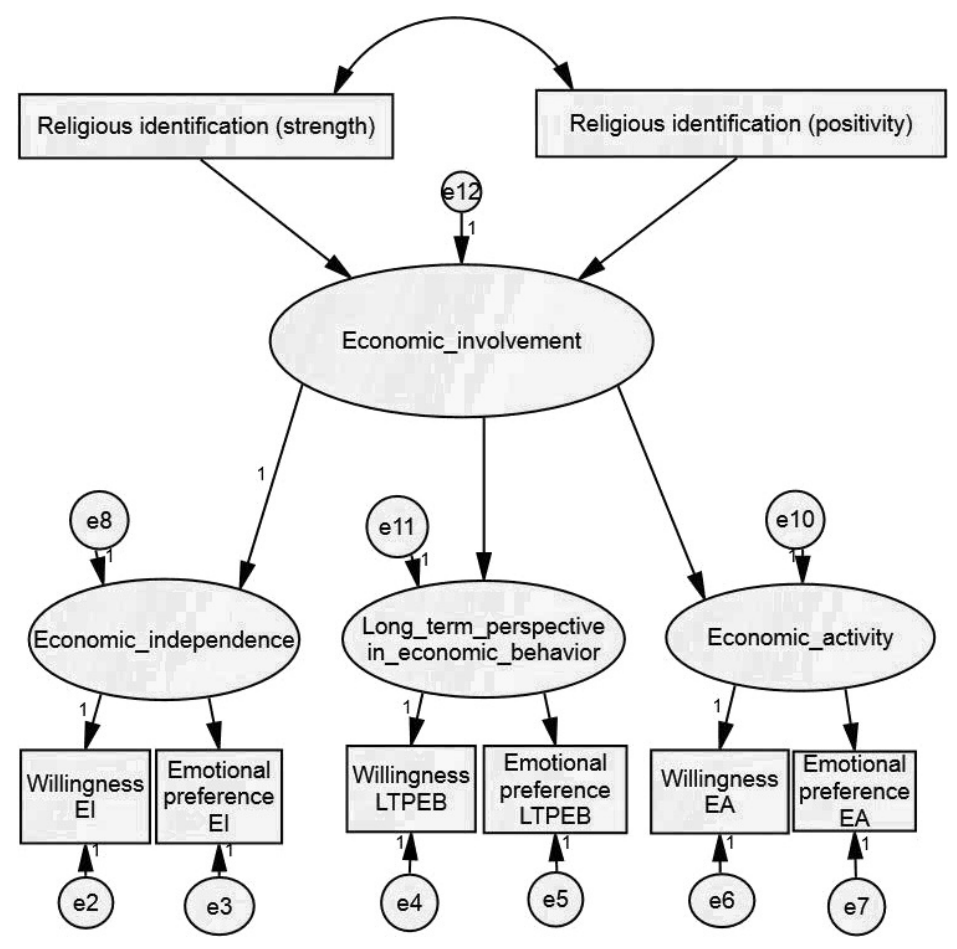

To test H1 (the relationship between strength and positivity of religious identification and models of economic behavior that reflect economic involvement attitudes) we used SEM. Figure 3 presents the model of the relationship between strength and positivity of religious identification and economic involvement in the representatives of Christianity and Islam. The results are presented in Figure 3. 
Table 4

The Relationship between Strength and Positivity of Religious Identification and Economic Involvement

\begin{tabular}{|l|c|c|c|}
\hline $\begin{array}{l}\text { The relationship between strength and positivity of } \\
\text { religious identification and economic involvement }\end{array}$ & $\begin{array}{c}\text { Combined } \\
\text { sample }\end{array}$ & $\begin{array}{c}\text { Christian } \\
\text { Orthodox }\end{array}$ & $\begin{array}{c}\text { Sunni } \\
\text { Muslims }\end{array}$ \\
\hline $\begin{array}{l}\text { Religious identification (strength) } \rightarrow \text { Economic } \\
\text { Involvement }\end{array}$ & $-.11^{*}$ & $-.11^{*}$ & $-.18^{*}$ \\
\hline $\begin{array}{l}\text { Religious identification (positivity) } \rightarrow \text { Economic } \\
\text { involvement }\end{array}$ & $.13^{* *}$ & $.12^{*}$ & .04 \\
\hline $\begin{array}{l}\text { Religious identification (strength) } \leftrightarrow \text { Religious } \\
\text { identification (positivity) }\end{array}$ & $.46^{* * *}$ & $.47^{* * *}$ & $.56^{* * *}$ \\
\hline
\end{tabular}

${ }^{*} p<0.05,{ }^{* *} p<0.01,{ }^{* * *} p<0.001$.

The characteristics of the unified sample models are: $\mathrm{CMIN} / \mathrm{DF}=1.83 ; \mathrm{CFI}=.99$; RMSEA $=.05 ;$ PCLOSE $=.94$; for multi-group (Christian Orthodox + Sunni Muslims): $\mathrm{CMIN} / \mathrm{DF}=1.30 ; \mathrm{CFI}=.99 ; \mathrm{RMSEA}=.02 ; \mathrm{PCLOSE}=1.000$. The regression weights in the whole sample, as well as in the two samples split by religious affiliation, are presented in Table 4.

The results indicated that strength of religious identification is negatively associated with economic involvement attitudes. We found the same results in the MGSEM on the Orthodox and Sunni samples.

Positivity of religious identification was positively associated with economic involvement models. However, in the MGSEM, this result was found only in the group of Christians.

In order to avoid multicollinearity between the strength and positivity of religious identification, which were found to be significantly correlated, we calculated variance inflation factor coefficient (VIF). The results showed that VIF is lower than 10. The tolerance indicator was also within acceptable limits $(>0.3)$, which excludes the presence of the direct effect between strength and positivity of religious identification. Therefore we concluded that there was no multicollinearity between these two variables.

When controlling for education $(\mathrm{B}=-.06, p>.05)$ and employment status $(\mathrm{B}=-.04, p>.05)$, the relationship of the strength and positivity of religious identification with economic involvement remain significant.

\section{Discussion}

This paper studies the relationship between the characteristics of religious identification and models of economic behavior in groups of Orthodox Christians and Sunni Muslims. The results are consistent with previous research and support the idea that religion is associated with attitudes toward economic behavior (Dana, 2009; Parboteeah et al., 2009; Hayward \& Kemmelmeier, 2011). 
We found statistically significant interfaith differences in religious identification: strength of religious identification is significantly higher in the Muslim group. Muslims are characterized by a close relationship between ethnic and religious identification, since maintaining religious identification is a means to preserve their culture and the boundaries of their own ethnic group. Positivity of religious identification was also significantly higher in the Muslim group indicating consistent and more pronounced religiosity.

The presence of positive identification among respondents of both faiths suggests that the identification is voluntary, with high value for the person in general; while the awareness of forced identification leads to unfavorable evaluations (Amiot \& Sansfaçon, 2011), in our results we recorded only positive scores.

Our study supported the hypothesis that strength of religious identification is negatively associated with economic involvement. S. Schwartz postulated that religious people showed lower levels of achievement and stimulation (Schwart \& Huismans, 1995). However, it is important to consider that those values form economically active behavior. For deeply religious Orthodox Christians and Sunni Muslims, the desire to take action in the economic sphere to increase material wellbeing, the willingness to build long-term prospects in economic behavior, and an interest in economics are nonessential. This confirms our assumption that lack of materialism in religious teachings is shared by members of the group and determines behaviors via social interaction. This hypothesis was supported both in the combined sample of Orthodox and Muslim people (SEM), and in two independent samples by religious affiliation (MGSEM). The hypothesis that positivity of religious identification is positively related to attitudes of economic involvement was also supported. It was revealed that positivity of religious identification promotes economic involvement attitudes. This is explained by the fact that the affective component of religious identification, i.e. actively participating achieves positive self-esteem (Tajfel, 1978), and promotes psychological well-being (Ashmore et al., 2004). Psychological well-being is closely linked to the active orientation of a person (such as autonomy and self-actualization) (Csikszentmihalyi, 1999). Thus, via psychological well-being, a positive religious identification promotes activity attitudes, in particular in economic behavior. However, this result was significant only in the group of Orthodox Christians, while positivity of religious identification did not have any effect on economic involvement among the Sunni Muslims. MGSEM showed that this relationship is also positive for them, though not statistically significant. The positive relationship between positivity of religious identification and economic involvement in the group of Christians can be explained by the fact that this group largely considers individual values, such as self-direction of thought and action, and openness to change, in a greater measure when compared to Muslims (Efremova \& Lepshokova, 2013). Therefore, members of first group have more freedom and opportunities for individual choice, including economic involvement as well. People of different religions have different religious norms that promote specific orientations (Parboteeah et al., 2009). For example, in Islam, participation and the quest for economic activity is considered a religious duty (Yosef, 2000), therefore it is part of their bonds with the community. Thus, rates of economic 
proactivity are higher in the group of Muslims than in the group of Christians. The lack of association between positivity of religious identification and economic involvement is not entirely surprising given the lack of variance in the responses to the positivity of religious identification measure. Indeed, the majority of responses were at (or very close to) the scale upper limit, suggesting a ceiling effect. This is consistent with M. Verkuyten's (2007) argument that Muslim identi cation is more like a nominal variable than a continuous variable, as one is either a believer or not (Triandis, 1992). Religious norms and rules affected by culture serve as behavioral guidelines. More importantly Islamic economic ethics is reflected in the sacred texts and in the system of doctrinal statements on economic relations. In Islam, laws defining and regulating market relations were formulated quite early (Susokolov, 2006).

When studying attitudes toward economic involvement in Muslims, it is important to look closely at the behavioral components of identity. It might help to identify more specifically how Islamic religious norms impact attitudes to economic involvement.

In our study we found that the strength and positivity of religious identification are associated differently with attitudes toward economic involvement.

\section{Conclusions and Limitations}

The link between religion and economic behavior has increasingly attracted scientific attention (Basedau et al., 2018). In our study we investigated relationship between strength and positivity of religious identification and attitudes towards economic behavior in a group of Orthodox Christians and Sunni Muslims in Russia. We found that strength and positivity of religious identification are related to economic involvement in a different way. In particular, strength of religious identification was not conducive to attitudes reflecting economic involvement. Positive religious identification was found to have a positive effect on economic involvement attitudes. Comparative analysis demonstrated that the relationship between positivity of religious identification and economic involvement has interfaith specifics: positivity of religious identification was positively associated with economic involvement only in the group of Orthodox Christians, while in the group of Sunni Muslims, this association was not significant due to the ceiling effect.

The current research offers important insights but some limitations should be noted. First, in the current study the sample was collected only in Russia. Orthodox and Muslims were represented by members of different ethnic groups. The same relationships should be tested in other ethnic/national groups. Second, there was a lack of consideration of moderating factors (social and political) which also impact economic attitudes and views. Third, we took a closer look at cognitive and affective components of attitudes through self-reports, but did not focus on the behavior itself. 


\section{References}

Albakova, F. U. (2009). Kanony sotsial'no-ehkonomicheskoj deyatel'nosti v islame [The canons of socio-economic activity in Islam]. In S. V. Pirogova (Ed.), Cennostnye orientiry v ehkonomicheskoj srede islamskogo mira [Values in the economic environment of the Islamic world] (pp. 37-46). Moscow: Mir'is. (in Russian)

Allport, G. W. (1950). The individual and religion. New York: MacMillan.

Amiot, C. E., \& Sansfaçon, S. (2011). Motivations to identify with social groups: A look at their positive and negative consequences. Group Dynamics: Theory, Research and Practice, 15, 105-127. doi:10.1037/a0023158

Ammerman, N. T. (2003). Religious identities and religious institutions. In M. Dillon (Ed.), Handbook of the sociology of religion (pp. 207-224). New York: Cambridge University Press. doi:10.1017/CBO9780511807961.016

Ashmore, R. D., Deaux, K., \& McLaughlin-Volpe, T. (2004). An organizing framework for collective identity: Articulation and significance of multidimensionality. Psychological Bulletin, 130, 80-114. doi:10.1037/0033-2909.130.1.80

Barro, R. J, \& McCleary, R. M. (2003). Religion and economic growth. American Sociological Review, 68(5), 760-781. doi:10.2307/1519761

Basedau, M., Gobien, S., \& Prediger, S. (2018). The multidimensional effects of religion on socioeconomic development: A review of the empirical literature. Journal of Economic Surveys, 32(4), 1106-1133. doi:10.1111/joes.12250

Benjamin, D. J., Choi, J. J., \& Fisher, G. W. (2010). Religious identity and economic behavior (NBER Working Paper No. 15925). Retrieved from https://www.nber.org/papers/w15925.pdf

Bergami, M., \& Bagozzi, R. P. (2000). Self categorization, affective commitment and group self-esteem as distinct aspects of social identity in the organization. British Journal of Social Psychology, 39(4), 555-577. doi:10.1348/014466600164633

Cohen, A. B. (2009). Many forms of culture. American Psychologist, 64(3), 194-204. doi: $10.1037 / \mathrm{a} 0015308$

Csikszentmihalyi, M. (1999). If we are so rich, why we aren't happy? American Psychologist, 54(10), 821-827. doi:10.1037/0003-066X.54.10.821

Dana, L. P. (2009). Religion as an explanatory variable for entrepreneurship. International Journal of Entrepreneurship and Innovation, 10(2), 87-99. doi:10.5367/000000009788161280

Efremova, M. V., \& Lepshokova, Z. H. (2013). Vzaimosvjaz' cennostej i ekonomicheskih ustanovok u rossijskih studentov: mezhkonfessional'nyj analiz [Relationship between values and economic attitudes in Russian students: Interconfessional analysis]. Kul'turno-Istoricheskaya Psihologija [Cultural-Historical Psychology], 2, 18-26. (in Russian)

Elçi, M., Şener, I., \& Alpkan, L. (2011). The impact of morality and religiosity of employees on their hardworking behavior. Procedia Social and Behavioral Sciences, 24, 1367-1377. doi:10.1016/j.sbspro.2011.09.135

Ellison, C. G. (1991). Religious engagement and subjective well-being. Journal Health and Social Behavior, 32, 80-99.

Freeman, R. B. (1986). Who escapes? The relation of churchgoing and other background factors to the socioeconomic performance of black male youths from inner-city tracts. In R. B. Freeman (Ed.), The black youth employment crisis (pp. 353-376). Chicago, IL/London: University of Chicago Press. doi:10.3386/w1656 
Glock, C. Y. (1962). On the study of religious commitment. Research Supplement to Religious Education, 57, 98-110. doi:10.1080/003440862057S407

Greenfield, E. A., \& Marks, N. F. (2007). Religious social identity as an explanatory factor for associations between more frequent formal religious participation and psychological well-being. The International Journal for the Psychology of Religion, 17(3), 245-259. doi:10.1080/10508610701402309

Guiso, L., Sapienza, P., \& Zingales, L. (2003). People's opium? Religion and economic attitudes. Journal of Monetary Economics, 50(1), 225-282. doi:10.1016/S0304-3932(02)00202-7

Guiso, L., Sapienza, P., \& Zingales, L. (2006). Does culture affect economic outcomes? Journal of Economic Perspectives, 20(2), 23-48. doi:10.1257/jep.20.2.23

Hayward, R. D., \& Kemmelmeier, M. (2011). Weber revisited: A cross-national analysis of religiosity, religious culture, and economic attitudes. Journal of Cross-Cultural Psychology, 42, 1406-1420.

Iannaccone, L. R. (1998). Introduction to the economics of religion. Journal of Economic Literature, 36(3), 1465-1496.

Kirchler, E., \& Holzl, E. (2006). Twenty-five years of the Journal of Economic Psychology (19812005): A report on the development of an interdisciplinary field of research. Journal of Economic Psychology, 27(6), 793-804.

Koval', T. B. (1994). Etika truda pravoslaviya [Orthodox work ethic]. Obshchestvennye Nauki i Sovremennost', 6, 55-70. (in Russian)

Kudryashova, I. V. (2012). Politicheskie izmeneniya i transformatsiya identichnosti v stranakh musul'manskogo Vostoka [Political changes and identity transformation in the countries of the Muslim East]. In I. S. Semenenko (Ed.), Politicheskaya identichnost' i politika identichnosti [Political identity and identity policy] (Vol. 2: Identichnost' i sotsial'no-politicheskie izmeneniya v XXI veke [Identity and socio-political changes in the 21st century], pp.155-184). Moscow: ROSSPEN. (in Russian)

Lea, S. (1999). Credit, debt and problem debts. In P. E. Earl \& S. Kemp (Eds.), The Elgar companion to consumer research and economic psychology. Cheltenham, UK: Edward Elgar Pub.

Lea, S., Webley, P., \& Levine, R. (1993). The economic psychology of consumer debt. Journal of Economic Psychology, 14, 85-119.

Parboteeah, K. P., Paik, Y., \& Cullen, J. B. (2009). Religious groups and work values: A focus on Buddhism, Christianity, Hinduism, and Islam. International Journal of Cross Cultural Management, 51(9), 51-67. doi:10.1177/1470595808096674

Putnam, R. (1993). Making democracy work: Civic traditions in modern Italy. Princeton, NJ: Princeton University Press.

Schwartz, S., \& Huismans, S. (1995). Value priorities and religiosity in four western religions. Social Psychology Quarterly, 58(2), 88-107. doi:10.2307/2787148

Susokolov, A. A. (2006). Kul'tura i obmen. Vvedenie v ehkonomicheskuyu antropologiyu [Culture and exchange. Introduction to economic anthropology]. Moscow: Russkaya panorama. (in Russian)

Tajfel, H. (1978). Social categorization, social identity, and social comparison. In H. Tajfel (Ed.), Differentiation between social groups (pp. 61-76). London/New York: Academic Press.

Tatarko, A. N., Kotova M. V., Agadullina E. R., \& Efremova, M. V. (2011). Metodika issledovaniya kul'tury i modeley ekonomicheskogo povedeniya [Research methodology for studying culture and models of economic behavior]. In N. M. Lebedeva \& A. N. Tatarko (Eds.), Tsennosti kul'tury i modeli ekonomicheskogo povedenija [Values of culture and models of economic behavior] (pp. 134-150). Moscow: Sputnik. (in Russian) 
Triandis, H. C. (1992). Comments on Hinkle, Brown and Ely. Revista de Psicologra Social, 3, 113-123.

Verkuyten, M. (2007). Religious group identi cation and interreligious relations: A study among Turkish-Dutch Muslims. Group Processes and Intergroup Relations, 10, 341-357. doi:10.1177/1368430207078695

Weber, M. (1978). Economy and society: An outline of interpretive sociology. Berkeley, CA: University of California Press.

Webley, P., Burgoyne, C. B., Lea, S. E. G. \& Young, B. M. (2001). The economic psychology of everyday life. Hove: Psychology Press.

WIN - Gallup International Association. (2012). Global index of religiosity and atheism. Retrieved from http://www.sidmennt.is/wp-content/uploads/Gallup-International-um-tr\%C3\%BA-ogtr\%C3\%BAleysi-2012.pdf

Yosef, T. (2000). Islamic banks and investment financing. Journal of Money, Credit and Banking, 32(1), 93-120. doi:10.2139/ssrn.845

Maria V. Efremova - senior research fellow, International Scientific-Educational Laboratory for Socio-Cultural Research, Expert Institute; associate professor, Faculty of Social Sciences, School of Psychology, National Research University Higher School of Economics, Ph.D.

Research area: social identity, religious identity, psychology of inequality.

E-mail: mefremova@hse.ru

Zarina Kh. Lepshokova - senior research fellow, International Scientific-Educational Laboratory for Socio-Cultural Research, Expert Institute; associate professor, Faculty of Social Sciences, School of Psychology, National Research University Higher School of Economics, Ph.D.

Research area: social and cross-cultural psychology, intercultural relations, acculturation, values, multiple identities.

E-mail: taimiris@yandex.ru; zlepshokova@hse.ru 


\title{
Религиозная идентификация и установки на экономическую вовлеченность у христиан и мусульман в России
}

\author{
М.В. Ефремова ${ }^{a}$, 3.Х. Лепшокова \\ ${ }^{a}$ Национальный исследовательский университет «Высшая школа экономики», 101000, Россия, \\ Москва, ул. Мясницкая, д. 20
}

\section{Резюме}

Данное исследование посвящено изучению взаимосвязи выраженности и позитивности религиозной идентификации с установками на экономическое поведение в группе православных христиан и мусульман (суннитов) России $(\mathrm{N}=820)$. Для измерения выраженности и позитивности религиозной идентификации сконструирована шкала на основе теории социальной идентичности. Измерение установок на экономическое поведение основано на сценарном подходе. В результате исследования обнаружено, что установки на три модели экономического поведения образуют единый фактор экономической вовлеченности. Кроме того, наличие единого фактора экономической вовлеченности было также подтверждено с помощью конфирматорного факторного анализа в двух религиозных группах. В исследовании обнаружено, что выраженность и позитивность религиозной идентификации по-разному связаны с экономической вовлеченностью. Выраженность религиозной идентификации отрицательно связана с экономической вовлеченностью, тогда как позитивность религиозной идентификации позитивно связана с экономической вовлеченностью. В результате мультигруппового моделирования структурными уравнениями выяснилось, что связь между позитивностью религиозной идентификации и экономической вовлеченностью имеет межконфессиональную специфику: позитивность религиозной идентификации положительно связана с экономической вовлеченностью в группе православных христиан, в то время как в группе мусульман данная связь оказалась незначимой. Полученные результаты обсуждаются с точки зрения особенностей религиозной идентификации представителей христианства и ислама.

Ключевые слова: религиозная идентичность, экономические установки, модели экономического поведения, экономическая вовлеченность, христиане, мусульмане, Россия.

Ефремова Мария Викторовна - старший научный сотрудник, Международная научноучебная лаборатория социокультурных исследований, Экспертный институт; доцент, департамент психологии, факультет социальных наук, Национальный исследовательский университет «Высшая школа экономики», кандидат психологических наук.

Сфера научных интересов: социальная идентичность, религиозная идентичность, психология неравенства.

Контакты: mefremova@hse.ru

Лепшокова Зарина Хизировна - старший научный сотрудник, Международная научноучебная лаборатория социокультурных исследований, Экспертный институт; доцент, департамент психологии, факультет социальных наук, Национальный исследовательский университет «Высшая школа экономики», кандидат психологических наук.

Сфера научных интересов: социальная и кросс-культурная психология, межкультурные отношения, аккультурация, ценности, множественные идентичности.

Контакты: zlepshokova@hse.ru 